Article

\title{
Resilient Governance of Water Regimes in Variable Climates: Lessons from California's Hydro-Ecological Zones
}

\author{
Jeff Romm 1,*, Esther Conrad ${ }^{2,3}$ and Inger Elisabeth Måren 4 (iD) \\ 1 Department of Environmental Science, Policy and Management, University of California Berkeley, Berkeley, \\ CA 94720, USA \\ 2 Gould Center for Conflict Resolution, Stanford Law School, Stanford University, Stanford, CA 94305, USA; \\ esther@stanford.edu \\ 3 Water in the West Program, Woods Institute for the Environment, Stanford University, Stanford, \\ CA 94305, USA \\ 4 Department of Biological Sciences, University of Bergen, 5007 Bergen, Norway; inger.maaren@uib.no \\ * Correspondence: jeffromm@berkeley.edu; Tel.: +1-510-406-5275
}

Received: 26 September 2017; Accepted: 2 February 2018; Published: 12 February 2018

\begin{abstract}
Highly variable water regimes, such as California's, contain distinctive problems in the pursuit of secure timing, quantities and distributions of highly variable flows. Their formal and informal systems of water control must adapt rapidly to forceful and unpredictable swings on which the survival of diversified ecosystems, expansive settlement patterns and market-driven economies depends. What constitutes resilient water governance in these high-variability regimes? Three bodies of theory—state resource government, resilience and social mediation-inform our pursuit of governance that adapts effectively to these challenges. Using evidence drawn primarily from California research and participation in the policy and practice of water governance, we identify two stark barriers to learning, adaptation and resilience in high-variability conditions: (1) the sharp divide between modes of governance for ecological (protective) and for social (distributive) resilience and (2) the separation between predominant paradigms of water governance in "basins" (shared streamflow) and in "plains" (minimized social risk). These sources of structural segregation block adaptive processes and diminish systemic resilience, creating need for mediating spaces that increase permeability, learning and adaptation across structural barriers. We propose that the magnitude and diversity of need are related directly to the degree of hydro-climatic variability.
\end{abstract}

Keywords: high-variability climates; resilient water governance; structural segregation; mediating networks

\section{Introduction}

\subsection{The Governance Problem in High-Variability Water Regimes}

Highly variable climate and water regimes present distinctive problems in the pursuit of security in timing, quantities and distributions of flows. Formal and informal systems of water control must adapt rapidly to dramatic swings in water regimes on which the survival of diversified ecosystems, expansive settlement patterns and market-driven economies depends. They must do so with the distinctive challenges of governmental and financial structures that typically are rooted in less stressful environments, technologies and institutions that embed past strategies in landscape and society and insufficient scientific capacities to mobilize for specific needs and times across their diverse conditions. Long-term climate change furthers the need for resilience [1-3] and adaptability $[4,5]$ within governance itself. 
What constitutes resilient water governance in highly variable climatic regimes? We define 'governance' to mean all social processes-governmental, informal, customary-that guide the collective actions of people [5-7]. 'Adaptive governance' includes the processes of learning, innovation, investment and modified actions that respond to perceptions of changing patterns of variability in, for example, climate, demographics, economy and polity [6,7]. 'Adaptive water governance' contains a distinctively scientific core because of its dependence on learning about water-related variability in the natural and social worlds and the dynamics that human actions and their technical instruments affect $[8,9]$. 'Resilience' - the capacity of a system to retain its integrity amidst shocks and contextual change-can involve protective insulation of opportunities from risk on the one hand, diversified diffusion of opportunities and risks on the other [10-12].

Social capacities that mediate between grounded hydro-ecological variability and structured governmental responses are fundamental in adaptive governance. We suggest that the magnitude and diversity of need for these capacities is particularly great when variability is high, in which case toward-the-ground learning and adaptation are more determining of outcomes and specialization within government more likely to open distance among its structured capacities.

Does the high variability of Mediterranean water regimes differentiate their governance requirements from those of less variable conditions? The work of the Mediterranean Water Group at UC Berkeley illuminated three observed patterns that suggest such highly variable regimes may have distinguishing requirements. First is the divide between scales and motivations of public action in pursuit of resilience for ecological and for social purposes. The ecological requires protection of highly diversified specialized organisms and habitats [13-17]; the social requires diversifying pathways for water movement across enlarging scales and differences of human settlement [18-23]. One seeks stability for the particular, a small reach of stream or single species, for example. The other pursues stability, amidst flood and drought, intense seasonality and spatial spread and diversity of settlement and economic activity, in an expanding universe of land and people. The two are governed by very different patterns of grounded social learning and adaptation and by stiffly separate specialized governmental authorities. The divides produce major governance challenges for mediation between the local and governmental and among the formal structures of government.

Second is the paradigmatic clash between water regimes typical of watersheds or basins, giving priority to coordination among actions and actors in a shared stream and governance arrangements common in the settled plains, coordinated through socially created infrastructure distribution networks among settlements and economies, irrespective of natural flows. The former derives from a model of unifying interdependence among uses and users of a common natural flow [24-30]; the latter focuses on the humanly constructed distribution of water opportunities and risks across often-vast and expanding reaches of settlement and activity [18-23]. Each contains embedded political, professional and organizational assumptions about the purposes, structures and processes of government-the basin giving priority to hierarchies of territorial jurisdiction and control, the plains to functional technocratic authorities that transcend territorial boundaries-and the kinds of adaptation and response they produce. The two paradigms create and rely upon segregated structures of political power, law, science, technology, education and professional and governmental organization. While water-tied 'basin' and 'plains' might be viewed from a managerial perspective as unified in shared purpose, authority and processes of governmental choice among means and actions, the reality for governance is one of sharply distinct formations of power, purposes, concepts, cultures, rules and systems of action.

Third is the prevalence of collaborative modes of mediation at problematic locations along the boundaries between the social and structural, between structures that are oriented for ecological and for social resilience and between those that assume basin or plains orientations of purpose, explanation and capacity [31-37]. Collaborative mediation increases the permeability and adaptation across boundaries and among scales; it may catalyze networks and influences outward across structural divides, mobilizing resources for response to problems that flash through high-variability regimes $[9,31]$. 
These observed patterns suggest several hypotheses about resilient water governance. High variability water regimes provoke specialized structural segregation in governments at a cost of shared learning and mutual adaptation. It increases needs, motivations and knowledge for mediating capacities at problem points between structural boundaries and between governmental structures on the ground. Relative to less-variable conditions, resilient water governance in high variability conditions shifts the balance of needed capacity from foreground governmental structures [38] toward the social background of potentials for mediation in which these structures are embedded [39].

\subsection{Theories of Resilient Governance}

Our inquiry is guided by and responds to three streams of scholarly literature. Each frames issues of governance in ways that locate high-variability conditions at the margins of its range.

\subsubsection{Resource Government}

The first stream focuses on theories of resource government, unified authoritative territorial hierarchies that pursue purpose, order and capacity for reasonably effective regulation of natural resources [8,19-21,24-27,38,40-43]. Although these theories explore a wide range of possible relations and balances-e.g., between centralized and local, technocratic and customary, uniform and diverse, specialized and contextual, coordinated and participatory-they ultimately embody norms of structural stability, prescribed explanation and specified effectiveness. Adaptation to new challenges occurs through processes within these bounds. Higher degrees of diversity and variability tend to push balances of effective control from state toward the local while specializing state relative to local functions $[44,45]$. At some limit, they hit the inflexibility that arises from primary structural commitments.

\subsubsection{Resilience}

The second stream focuses on social-ecological resilience, the capacity of systems to sustain their core processes amidst contextual shocks and variations [1-7,9-11,46,47]. Its norm of balance is a unifying adaptive mesh between social and ecological systems. When applied in governance, the continua of relations and balances flow from circumstances in which social and ecological systems mesh with one another in mutually adaptive ways to those at the margin in which such possibilities do not exist, in which the drivers of the ecological and the social do not connect. Beyond the margin, advocacy for or assumption of suitable structural adjustments tends to replace analysis of systemic conditions in which such adjustments may and may not occur or be effective.

\subsubsection{Social Mediation}

The third stream focuses on social mediation, flexible systemic capacities for framing human relations to advance learning, settle differences and solve problems in and among scales and structures of activity over time [39,44-51]. In resource governance, theories of mediation have been applied through collaborative methods to specific problems with great effect and have begun to move from specific problems toward more generalized networks that mobilize resources for diverse problems $[6,7,31-36]$. They have not yet broadened to the societal fabric of mediation that provides the buoyant background for network articulation and responses to pervasive stresses beyond their momentary eruption.

The high variability and diversity of water regimes in variable climates place them at or beyond the edges of these three bodies of theory. They are beyond the capacities of specific governmental structures, beyond the mesh between social and ecological systems and beyond problem-provoked mediation strategies. If variability and diversity were to set the central construct rather than reside outside its margins, we suggest that social mediation would emerge as fundamental rather than peripheral force in explanation and governance. Attention would shift from problem-driven adaptation in the foreground structures of government toward the background potentials for social mediation. 


\section{Materials and Methods}

This article is the product of collective interpretation, among the University of California Berkeley's Mediterranean Water Group (MWG) and its associates. The MWG has sought integrating principles from diverse sources of disciplinary motivation, governance and professional engagement, each with its own demands for valid method and explanation. Depending on researchers' disciplines, their work has passed scholarly review in ecology, economics, political science, geomorphology, hydrology, sociology, planning, geography, engineering and archeology. Scientific and professional purposes have included, e.g., the survival of a species or habitat [13-17], the production of food [23,29], safe and equitable water supply for mass consumption [21,52], flood and drought hazard reduction [22,42] and forest water storage and supply [35,36,53-55] Sites and scales have extended from localized and isolated circumstances in specific habitats of California's Russian River $[15,16,29,30]$ and ancient settlements in the Levant [56] to large scale technocratic modes of governance in California [21,22,42] the European Union [42] and, the Ganges-Brahmaputra Basin [57-63].

Informed by MWG research and discussion described above, we ground our analysis largely upon case studies in California. We draw cases from previous research by this paper's authors. Cases were selected to illuminate the potential range of social mediation for resilient governance in high variability conditions characterized by relatively rigid specialized structures of government and science. The Klamath case represents the growth of mediated adaptation between authorities for ecological protection and for social security. The Trinity and Feather represent resistance and mediation potentials between paradigms of basin or watershed and floodplain structures of authority, thought and action. Finally, to illustrate collaborative mediating responses to frequent drought, flood and longer-term climatic trends, we examine the cases of the Sierra Nevada Ecosystems Project (SNEP), the California Delta and the statewide Integrated Regional Water Management (IRWM) program. These California cases were chosen with a comparative eye toward less-variable climatic regimes, such as the eastern United States and northern Europe [42] and high-variability regimes, as in the Ganges-Brahmaputra [57,58,64-68] that are not of the Mediterranean type. Emergent patterns and their consequent hypotheses have been subject to three years of critique in MWG seminars, symposia and reviews.

\section{Results}

\subsection{Ecological Resilience vs. Social Resilience: Structural Segregation in Water Governance}

The greater Klamath River illustrates the structural tensions in governance for ecological protection and for social distribution of water in the context of California's highly variable climate. The Greater Klamath has two main branches. Its mainstem, the Klamath, stretches southeastward 254 miles from high desert conditions of California's Modoc Plateau and east of Oregon's Cascade Mountains to the Pacific Ocean north of Eureka. To the south, the Trinity River runs from high alpine country through temperate montane reaches in California northwestward to its confluence with the Klamath about forty miles from the sea. Although the Trinity basin is about $20 \%$ of the area of the Greater Klamath, it has about $40 \%$ of its natural flows.

The upper reaches of both the Klamath and Trinity are dammed and their flows diverted for agriculture. The federal Bureau of Reclamation (BOR) manages dam storage and releases in both branches but under different structures of law, administration, constituency and accountability. Four irrigation districts consume Klamath water, stored in Upper Klamath Lake, in the semiarid borderlands of Oregon and California. The Trinity is governed as a division of the federal Central Valley Project (CVP), in California. Fifty to ninety percent of its flows are diverted by tunnel through the intervening mountains to the Sacramento River and through the Sacramento-San Joaquin Delta for irrigation southward in desert conditions of the San Joaquin Valley. By gradual articulation of links, physical and governmental, between the federal CVP and California's State Water Project (SWP), with its key storage at Oroville Dam on the Feather River in the Sierra Nevada Range, Trinity waters 
have become part of the intricate network of substitutable flows, with options for alternate distributions when needed, that supply water to metropolitan Southern California as well as for Central Valley agriculture and the California Delta. The Klamath and the Trinity are distinct from one another in legal, political and administrative terms.

The Greater Klamath is crucial for salmonid populations and communities that depend on them $[37,43,59,60]$. Salmon need certain site-specific stream and flow conditions to thrive [15-17,59,60]. These conditions include quantities, timing, biotic and chemical qualities, temperatures, sediment loads and deposition patterns and stream reaches that fit the cyclical needs for regenerative upstream mobility and spawning. Dams have blocked migration pathways. Historically, agricultural demands, hydroelectricity generation, flood control and technical possibility have determined the management of releases $[37,43,59,60]$.

Salmon riparian habitats have also been transformed by localized activities spread throughout the Greater Klamath Basin, in mining, gravelling, logging, grazing, farming, fishing, transport and urban development. Such activities have long histories and continue today, governed by the interests and capacities of people who work in them. Concentrated particularly in tributary streams, their riparian impacts have been extensive, site-specific, highly diverse and largely unrecorded. In a vacuum of government, with small and dispersed population, numerous light-handed and disconnected jurisdictions and complex overlays of disparate plausible legal claims, these activities and their impacts have been largely uncoupled and uncontrolled.

In governance terms, salmon populations have been trapped between federally controlled upstream dams and diversions, state systems of consumption-oriented water rights and highly dispersed site-specific private uses within weak localized jurisdictions and loose social relations. [37,59]. Salmon species, as well as sucker species in Upper Klamath Lake, have suffered serious declines [59,60].

Three convergent forces have shocked this governance trap in recent decades. Drought eliminated water supply sufficient to sustain both irrigation district diversions and in-stream flows. The Endangered Species Act (ESA) emerged as a powerful control on water allocations to achieve more favorable in-stream flows [37,43,59]. Accelerated judicial expansion of tribal livelihood rights, stipulated in treaty, congressional reservation and executive decision, strengthened tribal claims for sufficient water to support salmon and sucker populations [37,61-63,69,70]. In the 1990's, the Klamath tribe of the Upper Klamath sponsored scientific studies that demonstrated impacts of water diversions on salmon and sucker survival. These studies gained influence when drought hit in 2001, stimulating ESA assertion of power amidst authorities that were too sparse or stiff to respond to the challenge of growing claims amidst extreme water scarcity.

The severe drought of 2001 brought the ESA and tribal rights to the center of Klamath water governance issues. [37,59,60]. ESA activation forced the Bureau of Reclamation to stop irrigation district diversions in the upper Klamath to meet minimum lake standards for the sucker and downstream flows for the salmon. Agricultural impacts of the stoppage had drastic effects on farmers, irrigation infrastructure, dependent communities and the regional economy.

Water stoppage shook the customary and financial as well as legal and administrative bases of irrigated agriculture. Although the BOR governs water diversions through laws and contractual arrangements that condition allocations on water availability, fisheries needs and other demands, operations over almost a century had produced stable irrigators' expectations that were embedded in intensive crop and land management systems, in property values and thus in the capitalized basis of agricultural credit, a dominating force in the stability of and potential stress in farm communities and regions [59,71]. Acculturated agricultural expectations, supported by federal policy, had hardened de facto priority of agricultural water claims relative to others. Diversions have depleted or disrupted river flows, particularly in times of shortage. This reality was key in the Fish and Wildlife Service Biological Opinion under the ESA that forced BOR stoppage of irrigation flows.

ESA application provoked another kind of drama. Longstanding federal territorial agencies-the Forest Service, Bureau of Land Management, Bureau of Reclamation-control 
a predominant share of the land in the upper Klamath and Greater Klamath generally, managing it within congressional utilitarian mandates and structures that have changed relatively little over a century and have sustained similar patterns of cultural expectation. The activated ESA mobilized upstream movement of authorities and capacities-National Marine Fisheries Service, Fish and Wildlife Service, Environmental Protection Agency-empowered by a later generation of environmental laws and still evolving in functional expertise, operational reach and political base. In the setting of the Klamath, the territorial old and environmental new agencies, with distinctively different roots, constituencies, purposes and adaptability, clashed in the weakness of relationships among them.

The agricultural desolation and economic collapse following water curtailment provoked deep reactions. Farmers blamed Indians and the BOR for their crisis. Both withdrew to evade violence. Race relations have a profoundly troubled history in the region. Hostility toward federal authorities is a steady undertone in daily discourse. Reactions to water curtailment pulled the upper Klamath region from quiet ebbs of the political margin toward central currents of state and federal interest [37,59].

Science played significant roles in the conflict. Different scientific endeavors, each with its own strengths, purposes and authorities, produced different interpretations, triggered different patterns of political formation and supported different government responses, all of which took effect through the different structural pathways they served.

Sponsored by the Klamath Tribes, Oregon State University (OSU), Tribal and Fish and Wildlife Service, scientists, with deep ecological research history and professional credibility in the region, provided the scientific basis for the Biological Opinion that stopped irrigation diversions for ESA protection of the endangered lake sucker and anadromous salmon species. This work began to force relationships between upstream and downstream federal agencies and the Klamath Tribes, with public accountability vested primarily in the courts.

A cooperative OSU-University of California (UC) scientific team, composed of academics with broad disciplinary but not necessarily regional expertise, analyzed curtailment impacts and potential adaptive responses in the Upper Klamath region [59]. It was a widely public endeavor, presenting its considerations in open settings at different stages. As consequences of its work, federal and state financial relief flowed into devastated agricultural communities, mobilized interest groups and new collaborations throughout the Klamath and stimulated Oregon and California state attention to investments in water banking, groundwater access and water conservation.

The National Research Council, at White House and Cabinet request, fielded a nationally recognized expert team to evaluate the scientific validity of the link between species survival and streamflow and lake levels upon which the curtailment had been justified [72]. The team concluded that, while the link may exist, its strength had not been proven amidst the many other influences on species demographics, habitat qualities and survival. This conclusion supported the federal development of inter-agency consultative arrangements and federal decisions to reopen agricultural diversions in 2002.

The scientific interplay deepened and stimulated but did not settle debates. What the science teams did share, however, was a confinement of scope that placed BOR management of diversions as the focal center of their inquiries. This had the effect of supporting the reflexive farm vs. fish, economy vs. environment, framing of water discourse, organization and government. For example, the OSU-UC science team, while undertaking a comprehensive assessment, centered its focus on the irrigation systems and dependent communities and river reaches above and below the irrigation diversions, with primary attention to the relationship between agriculture and fisheries. Public presentations drew hundreds of participants, primarily from the agricultural community and regional environmental groups. Issues were constructed, by citizens and scientists alike, in the accustomed political dichotomy of economy vs. environment. Tribal representatives were absent.

Construction of the science reflected the localized agricultural and environmental frames of interests that shaped early definition of problems. While the scientific endeavors provided no closure on 'truth', they initiated arenas for public discourse that stimulated expansive new questions, opened 
public spaces in which new relationships formed, catalyzed networks of groups that pressed outward from the initial construct of the problem toward broader contextual interpretation and action and gradually spawned working groups and agreements that crossed conventional divides among interests, authorities and jurisdictions [37,59].

Although the Klamath tribe had sponsored the initial fisheries study that triggered ESA application, tribes were not included in the framing, execution or review of the comprehensive scientific evaluation of the impacts of blocked diversions, nor did studies extend downstream. Exclusion motivated social mobilization. Tribes of the Greater Klamath - the Klamath, the Karuk, the Hupa and the Yurok-reaching in that order from the high plateau to the delta-have distinctly different original cultures and languages, territories and political systems. There is no particular tendency for collaboration beyond sporadic and localized or familial relations. However, they share the centrality of salmon in their cultures and economies. They share histories of white oppression and its contemporary forms. They share persistent struggles to be acknowledged as sovereigns, as more than another interest group. Although withdrawing in early stages, they gradually coalesced around the protection of the salmon and opportunities to advance claims to resources and sovereignties. Along with the entry of the marine fisheries industry and its cooperation with environmental groups, tribal coalition brought the whole mainstem Klamath into an evolving frame that stretched the Upper Klamath frame of the science teams. The Trinity remained beyond the scope of consideration, treated as if a separate river.

In 2002, the federal government reopened diversions to the Klamath Irrigation Districts. In late summer, approximately 40,000 salmon died near the mouth of the Klamath. An immediate reaction was to blame the diversions. The catastrophe came to be explained as disease-caused in conditions of low flow and high temperatures that favored parasites [37,60]. It opened questions about localized and Trinity sources of influence on water qualities and flows. An emerging basin-wide coalition for mainstem dam removal dampened these issues in favor of targeted organization but introduced a source of future divide in the tribal coalition. The Hupa, who reside on the Trinity rather than the mainstem, rejected severance of Trinity flows from consideration of forces in salmon survival.

Federal resistance to Trinity inclusion, perhaps to avoid the complexities of CVP government [73], did not stop Hupa initiatives in expanding their influence. The Hupa diversified pathways of influence in Washington, D.C. It protested irrigation claims in the Central Valley, actively sought relations with water districts dependent on the Sacramento and Delta and initiated court cases to increase instream flows. It began to challenge interests of the San Joaquin Valley's Westlands Water District, the primary beneficiary of Trinity water, gaining allies particularly among environmentally committed urban water districts. It gained a series of court decisions and injunctions that increased protection for Trinity instream flows relative to diversion commitments [74].

The fish-kill catastrophe also pulled attention toward localized farming and other land uses thought to affect downstream water quality, in the Scott, Shasta and Salmon River tributaries of the mainstem. Farmers organized in opposition to environmental pressures as well as for innovations in water management, activating county politics and engagement $[75,76]$.

In just a few years, an institutionally sparse region rapidly gained depth through civic coalescence and engagement. Mainstem councils, agreements and programs ranged in scope from the interagency and intertribal working groups, stakeholder committees at various levels, county boards of supervisors and cooperative science and management programs.

The adoption of a common foe, the mainstem hydrogeneration dams, accepted by many groups as the primary barrier to salmon migration, provided focus for momentary unification of interests in the Klamath. Oregon and California joined in pursuit of federal dam removal. Congress approved removal but then rejected finance for it, a defeat that temporarily transferred pressures of conflict toward other boundary issues.

The large gap in governance between the Klamath and the Trinity was one such issue. The Hupa withdrew from Klamath agreements over the Trinity exclusion. As court opinions now stand in cases brought by the Hupa and Yurok, fish- and tribe-friendly inflow regimes in the Trinity 
have gained weight in judicial balances with the contractual obligations for diversion exports. Fisheries-oriented programs, committees and working groups have strengthened fabrics of social engagement. Nevertheless, the larger-scale reach of Trinity issues and their impacts on the Klamath, as well as local needs to manage water within more comprehensive responsibilities for social wellbeing and fairness, forecast future stages of conflict and evolution in governance.

\subsection{Floodplain vs. Basin: Competing Paradigms of Water Governance}

When flows of the upper Trinity River were diverted into the federal Central Valley Project, this tributary of the Klamath was redefined as an administrative division of the CVP. Part of a river basin on the one hand, the Trinity became part of an expansive system of infrastructure on the other, governed for floodplain irrigation and drainage, flood management, urban and industrial needs. The Trinity shifted from a basin paradigm of governance, for resolving clashing sovereignties, agencies and interests that converge in a shared stream, to one instead structured, physically and socially, to capture and spread flows, drawn from many sources and crossing jurisdictional boundaries of all kinds, for secure, safe and equitable distribution to tens of counties, hundreds of irrigation and municipal districts, millions of homes, major industrial regions and a population that has quadrupled and sprawled over vast areas since the diversion. Mediation between these two systems of governance occurred through constitutionally-rooted judicial powers.

For our purpose, we use the terms 'basin' and 'floodplain' to identify these distinctive paradigms of water governance. The boundaries of a basin, from ridgetop through valley to delta and sea, set by geomorphology and climate, forge problems of governance that derive from the convergence of diverse powers and interests within a common stream they all claim and mutually affect. Floodplain governance instead focuses on boundless expansion of infrastructural networks for safe and sufficient distributions of water upon which people depend, wherever they are located and for whatever purposes. While basin governance presents the problem of ecological economic mesh within a bounded system, plains governance must give priority to conflicts between urban industrial agricultural complexes of power that are connected by humanly created structures. These different problems of governance shape separate legal, jurisdictional and administrative frameworks, different configurations of and arenas for political power, culture and constituency, different paths of scientific and technological development and distinctive agency, professional and educational institutions.

The difference between basin and plains paradigms of water governance gained dimension when, in successive weeks of 2014, a MWG Berkeley workshop on floodplains management and a Berkeley/Kathmandu workshop on Himalayan rivers revealed little overlap in concepts, explanations, constituencies, jurisdictions, suites of technology and modes of governance, even when focused on territory in which both could apply. The differences emerged not from location but about participants' unspoken assumptions about the political institutional content of these two ways of visualizing water systems. In each case, those outside the dominant paradigm, opposites in the two cases, were silenced despite sharing common vocabularies and sites.

Engineers dominated the floodplains workshop, with heavy emphasis on structural modes of water control. Another category, the 'nonstructural', gained general but vague concern, including anything that fell outside of the structural paradigm, including the world of ecological management practices identified with 'basins' or 'watersheds'. The workshop recalled the California Water Atlas [18], a richly detailed and effective compendium of data and maps about California's water resources and structural requirements to distribute them for the needs of cities, farms and industries. The book devoted one paragraph to 'watersheds', which meant the vast but politically separate federal montane forests, sources of most of the capacity within California for water storage, flow and vegetative water consumption.

The Himalayan workshop rode on the basin paradigm, emphasizing the infinite sources of influence on competing benefits of rivers-storage, power, farming, fisheries, navigation, sacredness, adventure. Little attention was paid to the plains, even though these penetrate through valleys 
into the very heart of mountains and montane settlement. This was not a matter of choice but of the unquestioned ecological framing of rivers. Participants from Bangladesh and the Gangetic Plain of India, home to half a billion people in high-risk flood prone and irrigation-dependent areas, massive infrastructure systems and densely populated cities, governed by vast powerful expert technocracies [64-68] floundered outside the discourse.

While public works technocracies can be said to be at the core of water governance in the plains, the basin concept focused attention on the control and uses of land, from plot, farm and village to district and national ranks of territorial jurisdiction. One author of this paper recalled a commission elsewhere to establish a national soil and water research agenda, which collapsed in battle over the definition of 'watershed'. Engineers saw a blue-laced brown map, spotted with towns and lined with dams, levees and canals, with slight green fringes on the edges; ecologists saw a green map with slight blue lines passing through it. The sciences could not be meshed. While the Berkeley and Kathmandu workshops were collegial, silent competing ideologies affected their outcomes.

The two paradigms are foundational to the governmental structures of scientific disciplines, professional education, resource agencies and laws. They embed assumptions of purpose, authority, key explanatory relationships, codes of validity, identity and values. The paradigmatic divide shapes conventions of thought, organization and action that resist adaptation to changes in sources, distribution and impacts of variability.

The Feather River offers an example. The principal tributary of the Sacramento River, in the Sacramento Valley of Northern California, the Feather is the source of water supply for California's State Water Project (SWP). Flowing into the Oroville Dam, after passing through a chain of hydroelectric generation facilities, the Feather is a source of flood risk and irrigation water in the Central Valley as well as major water supply for 25 million people in metropolitan Southern California. Water is a state authority. The upland watershed is primarily federal territory authorized to protect and manage forests. While the state paradigm of water control is primarily downstream, structural and distributive, the federal paradigm is territorial, ecological and vegetation-oriented. Although water supply was an initial purpose of the national forests $[77,78]$, it has become a passively protective background concern $[27,28,53]$.

The state relies on dams for storage. Federal watersheds store water in snowpack, meadows and vegetated streambank resistance to groundwater discharge. Over more than a century of logging, mining, grazing and other transformative land uses, the watershed of the Feather has become laced with a dense fabric of roads, ditches, mining scars, denuded streams, clearings, cattle paths and gullies that accelerate water drainage as well as soil loss. The paradigmatic divide between federal watersheds and state storage and distribution systems has prevented the enhancement of watershed storage capacities. Neither means nor motivations have been available to cross government boundaries to modify federal management practices for storage purposes. Recent breaches of the Oroville Dam [79] illustrate the brittleness borne of belief that the map is either structurally blue-laced brown or lightly blue-lined green, political barriers supported, albeit not created, by distinct educational, scientific and professional rationales.

Several decades ago, a local collaborative group mobilized to open pathways for plains support of basin watershed improvements despite jurisdictional barriers. The Feather River Cooperative Resource Management Group (CRMG) developed information about, sought support for and implemented mutually beneficial opportunities that required minimal adjustments of formal authorities $[26,35,80,81]$. It has restored streams and stabilized streambanks, plugged meadows and gullies to lift groundwater storage and delay releases $[78,82,83]$. It has pressed successfully for reduction of national forest road networks, which had been extensive enough to form drainage systems alternative to natural streams. Most of this work has occurred on federal lands with financial support from downstream urban agencies reliant on Feather water for consumption and electricity. A collaborating industrial forest neighbor undertook group-selection silvicultural practices, creating forest pockets that trap snow, 
increase shade, reduce temperatures and delay melt [54,55,84-86]. Climate warming and declining snowpack would increase the value of delay.

The Feather River CRMG inspired community watershed groups throughout the Sierra and montane California. Over time, it drew increased engagement of the Forest Service, the Los Angeles Metropolitan Water District, academic and community-oriented scientists [81] and the California Department of Water Resources (DWR). It stimulated strengthening of hydrological capacities within the Forest Service [78] and watershed management capacities within the DWR [34], building appreciation for the importance of localized mediation as catalyst for adaptations that did not necessarily challenge or change water law or agency authorities. Its strength emerged partly from its proven utility in the functional vacuum between segregated paradigms.

Two cases provide examples of statewide public mediation between floodplains and basin paradigms. In these cases, federal initiative created space for public framing of issues across paradigmatic and governmental boundaries. Congress created the first of these, the Sierra Nevada Ecosystem Project (SNEP) [87] to establish scientific basis for resolution of conflicts that had stymied federal management of the Sierra Nevada's forests. More than a hundred scientists converged to achieve an integrated foundation for decisions about how to allocate, use and sustain the forest ecosystems of the Sierras. After several years of consuming effort, what emerged were, with some exceptions, packets of discrete high-quality disciplinary science that did not fit together apart from the jurisdictional frame of the Forest Service [88]. SNEP leaders then opened the science to public review, in local as well as statewide settings. The consequence was not significant challenge of the empirical science itself but a different framing of the Sierra Nevada that augmented disciplinary with public and professional values and interpretations of evidence. SNEP's primary organizing frame shifted from jurisdictional layers of elevational ecosystem types and site conditions, sampled in accord with disciplinary expectations, to a range of elevationally transecting basins of water storage and flow that fit public concepts. The change unified necessarily fragmented findings in a water-focused interpretation with which publics and diverse agencies, as well as scientists, felt comfortable.

The second case, the CALFED program [32,33,89-91], was created to find solutions for the tremendously conflicted California Delta, the State's nerve center for water distribution and drainage. Water from the north, including Trinity and Feather water, flows into the Delta, then to be pumped southward for distribution to agricultural and metropolitan uses. Residing in the heart of the Central Valley and San Francisco Bay Area amidst rich agricultural and growing metropolitan and industrial pressures, hundreds of local and state authorities and civic organizations have some form of jurisdiction or stake in the Delta's functions and conditions. The combination of the intense demands placed on this system and California's highly variable precipitation patterns regularly stir conflict between farmers and cities depending upon water deliveries and federal and state agencies charged with protecting endangered fish species and the functioning of the fragile Delta ecosystem. In addition, global warming is hastening melt of the Sierra snowpack while sea level rises have the potential to lift the tidal dam of increased flows to the Pacific, with mounting pressures on levees that surround flood prone farms and cities for up to a hundred miles north and south.

In this pressurized maze of jurisdictions and interests, the Delta's ecological vulnerability and endangered species triggered federal ESA application and CALFED sponsorship. Through CALFED, a relatively open-ended complex of linked collaborative arenas, self-organizing to one degree or another, formed to mediate the intense claims and authorities in the Delta on intra- and inter-annual timescales to cope with the demands of wet and dry years and to frame the basis for programs and investments responding to its needs [32,33,89-91]. One consequence was an immense growth of scientific and public knowledge about a critical system that previously had fallen to the margins of prevailing structural paradigms. Another was a spirit of inclusivity, identity and mutual regard in what had been jurisdictionally chaotic conditions. CALFED processes catalyzed extensive networks that continue to expand influence across barriers of paradigm, jurisdiction, ideology, race, class, discipline and profession. Although its solutions were partial relative to its grander aspirations, it established 
fabric and process for governance that continues to generate new responses to the Delta's problems. CALFED nurtured rapid growth of the field of collaborative mediation, in concept and practice and its related advance of governance as the resilient social ground of governmental structure. For example, DWR, a historically classic technocracy, drew upon CALFED experiences as it undertook a transition of the California water planning process from a sole focus on statewide water supply infrastructure toward an open, multi-stakeholder collaborative process engaging with localized and regional-scale efforts to meet the state's water needs [33]. As this transition took place during the 2000s, DWR began to actively support collaborative processes at the regional scale through the Integrated Water Resources Management (IWRM) program, aiming to support mediating spaces and strengthen adaptability to region-specific conditions. Regionalized spaces produced unique collaborations, diagnoses, strategies and patterns of investment. Although framed politically as a response to climate change, the grounded practice of decentralized mediation has demonstrated the centrality of variability and diversity in water governance whatever climatic shifts may occur [33,42]. The IRWM planning process, which emerged with a focus on water supply reliability, made incremental steps toward integrating planning for flood management in some regions. In the Central Valley, where the state has historically played a significant role in managing flood risks, DWR supported the creation of a new set of Regional Flood Management Planning regions, which provide a forum for local stakeholders to participate in identifying priorities and solutions that move beyond a sole reliance on hard infrastructure [22].

Congressionally required short time horizons for CALFED investments limited its focus on 'watersheds' as reaches of the Delta system, although funding has been targeted to regions participating in the IRWM program toward reducing pressures on the Delta. Perhaps coincidentally, Forest Service reinterpretation of the SNEP report withdrew from water flows to the original forest ecosystems framing of SNEP science, thus to its territorial paradigm of jurisdiction. Civic organizations have mobilized, basin by Sierra basin, to initiate mediation and adaptive permeability suited to their locales.

More recently, the extreme conditions generated by the 2012-2016 drought in California have heightened tensions between ecological and social purposes and "basin" and "plain" styles of governance. The drought galvanized long-delayed steps toward management of the state's groundwater resources, which, in times of scarcity, have served as a "safety valve" for farmers with access to groundwater pumping. Without the ability to continue depleting groundwater resources when droughts persist, farmers, environmental advocates and others have sought to create new mediated spaces in which solutions can be negotiated [33].

\section{Discussion}

\subsection{Structural Resistance and Social Mediation}

We have offered representative examples of how the structures of government and science in California have created stiff barriers that block potential pathways for responsive adaptation to variability, shock and longer-term trends. These examples display the importance of mediating capacities that soften barriers, reframe issues and open pathways for more resilient learning and response. In all of these examples, resilience grew through relative movement from structure-dominant government toward the mediating nodes of an emergent social fabric of governance that made adaptation possible.

In addition to structural resistance, a characteristic of all regimes, high variability water regimes face the unbridged chasms [47] between specialized structures, each integrating its own distinct and internally unified sources of frame, purpose, place, value, knowledge, capacity and risk. The Klamath-Trinity divide is a classic example of structural segregation. Divides between the territorial and the environmental agencies within the Klamath or the Delta are others. There is no natural mesh, no 'fit' of the kind that may be imaginable in less variable water regimes or imposed in the interest of administrative order and simplification. 
If learning, adaptability and resilience are sought in these circumstances, the social potential for mediation is fundamental. Its visible emergence may occur organically, to solve particular problems, then fade, transform, coalesce, spawn, extend or disappear. In the Klamath and Feather, it emerged as relatively spontaneous developments outside of government structures, even as reactions to them, expressing social impulses to resolve problems that lacked structural solutions. In other cases, as in the Integrated Regional Water Management (IRWM) and CALFED programs, governments recognized the need and sought to open and support spaces within which self-organizing mediation could develop.

In all of these cases, an underlying social fabric had the latent coherence to mobilize and focus its potentials for adaptive relationships across and through sources of structural resistance. The Greater Klamath region moved from a structure-dominant toward a more resilient social fabric of governance, rippled by shocks that revealed structural incapacity for adaptive responses. The Feather River Working Group brokered urban investment in meadow storage on federal watershed lands, stimulating similar efforts elsewhere.

\subsection{Mediation Potential as Source of Resilience}

Mediation shapes all relationships at any social scale [31,39]. While judicial systems are structural expressions, the reality is a pervasive buoyant framing of norms and possibilities within which different parties adjust to one another at and among all scales of social life [39]. In addition to organization charts of formal authorities, functions and capacities, water governance can also be visualized as dynamic maps of floating and flexible arenas of mediation, in different spatial, social and temporal scales, within which participants are relatively free of structural constraints to identify and confront boundary problems. The balance between structure and social mediation is a variable in governance that appears to rise in significance with variability.

If resilient governance is the purpose, one need is for strategic means to strengthen the buoyancy, mobility and convergence of these potentials $[5,6,9,31,46,47]$. Despite growing prevalence and effectiveness of problem-oriented mediation, there is yet little strategic perspective of their aggregate functions and how to support them as foundational rather than incidental, opportunistic or episodic aspects of water governance. A strategic perspective might include, for example, the institutionalization not of form but of memory, learning, access, mobility, anticipation, guidance and potential response. Scientific networks might be nurtured as flexible sources of talent for convergence in boundary sites of rising stress.

\subsection{Scientific Mediation for Resilient Water Governance}

Our illustrations show the importance of scientists' roles as sources of diverse logics that bring alternative conditional frames and bodies of evidence to governance boundary problems. They also show how social mediation brings logics that help scientists surmount their own structural barriers. The government of disciplines enforces its rules stiffly through criteria of merit, evaluative structures, publication, cultural compliance and reward systems. Public and professional engagement helps scientists to overcome such structural barriers to learning, adaptation and responsive governance.

\section{Conclusions}

We began this article with several hypotheses about resilient water governance in high-variability hydro-ecological regimes. The greater the variability in water regime, the stronger is the structural segregation of governmental water authorities and the concepts that rationalize them. The stronger the structural segregation, the more extensive, diverse and dynamic are the mediating capacities needed to achieve learning and adaptation in governance. The greater the variability, the greater is the significance of background social mediation potentials relative to foreground structures of government and science for resilient water governance. Our cases suggest the plausibility these hypotheses.

California's experience suggests the fundamental importance of social mediation capacities between highly diverse spatial distributions of variability and relatively brittle relations with and 
between segregated structures of government. Despite this importance, these capacities draw little systematic attention relative to the investments for learning and adaptation within governmental structures. If resilient governance is sought, we propose the balance would shift from the foreground of structure toward the ubiquitous background of potential social mediation.

Does this proposition have relevance beyond California? To answer this question, comparative studies of three kinds seem to be needed. The first would be with water governance regimes in other Mediterranean states in e.g., Southern Europe, West Asia and North Africa. Second would be among regimes that appear to manifest equivalent priority for social mediation but in different hydro-ecological conditions, in the Chesapeake, Everglades or Northern European regions for example. Third would be comparison with water governance regimes that appear to achieve governmental integration that, with minimal autonomous social mediation, is able to effectively comprehend the ranges of variability to which they must respond, i.e., in which government and governance are reasonably equivalent.

A different kind of challenge is explanation of the actual content of the social mediation 'layer', how and why it maps with distributions of variability, how and why it converges, grows, drifts and declines in different conditions. In our cases, few of the participants in social mediation were driven solely, or even primarily, by their interests in water, nevertheless converging around water issues when given reason, opportunity and scope to do so. Comparative studies of concrete cases and observable network dynamics—-these in water governance are accessible—would deepen understanding of social motivation and capacity. The more difficult task is to discover deep stories of adaptive social dynamics, from the expansive literatures strewn across many fields, as these might become expressed specifically in resilient water governance. Successful examples involve people and groups pulled by multiple motivations that may or may not be tied to water, yet forged together in a particular moment achieve remarkable collective power in water governance.

Acknowledgments: We acknowledge the following sources of support for the work on which this article is based: UC Berkeley Institute of Governmental Studies, California Department of Water Resources, National Science Foundation, University of California Water Resources Center, United Nations Development Programme and the Ford Foundation.

Author Contributions: Jeff Romm conceived and designed the study. Esther Conrad, Jeff Romm and Inger Elisabeth Måren performed the empirical investigations, data analysis and interpretation. Jeff Romm, Esther Conrad and Inger Elisabeth Måren wrote the paper.

Conflicts of Interest: The authors declare no conflict of interest.

\section{References}

1. Folke, C. Resilience: The emergence of a perspective for socio-ecological systems. Glob. Environ. Chang. 2006, 16, 253-267. [CrossRef]

2. Folke, C.; Pritchard, L.; Berkes, F.; Colding, J.; Sved, U. The problem of fit between ecosystems and institutions: Ten years later. Ecol. Soc. 2007, 12, 30. [CrossRef]

3. Folke, C. Resilience and sustainable development: Building adaptive capacity in a world of transformations. AMBIO 2002, 31, 437-440. [CrossRef] [PubMed]

4. Adger, W.N.; Hughes, T.P.; Folke, C.; Carpenter, S.R.; Rockström, J. Social-Ecological Resilience to Coastal Disasters. Science 2005, 309, 1036-1039. [CrossRef] [PubMed]

5. Franks, T.; Cleaver, F. Water Governance and Poverty: A framework for analysis. Prog. Dev. Stud. 2007, 7, 291-306. [CrossRef]

6. Blackmore, C.; van Bommel, S.; de Bruin, A.; de Vries, J.; Westberg, L.; Powell, N.; Foster, N.; Collins, K.; Roggero, P.; Seddaiu, G. Learning for Transformation of Water Governance: Reflections on Design from the Climate Change Adaptation and Water Governance (CADWAGO) Project. Water 2016, 8, 510. [CrossRef]

7. Folke, C. Adaptive Governance of Socio-ecological Systems. Annu. Rev. Environ. Resour. 2005, 30, 441-473. [CrossRef]

8. Lee, K. Compass and Gyroscope: Integrating Science and Politics for the Environment; Island Press: Washington, DC, USA, 1993. 
9. Booher, D.; Innes, J. Governance for Resilience: CALFED as a Complex Adaptive Network for Resource Management. Ecol. Soc. 2010, 15, 35. [CrossRef]

10. Gunderson, L.; Holling, C. (Eds.) Panarchy: Understanding Transformations in Human and Natural Systems; Island Press: Washington, DC, USA, 2002.

11. Gunderson, L.; Pritchard, L. (Eds.) Resilience and the Behavior of Large-Scale Systems; Island Press: Washington, DC, USA, 2002.

12. Berkes, F.; Colding, J.; Folke, C. Navigating Social-Ecological Systems: Building Resilience for Complexity and Change; Cambridge University Press: Cambridge, UK, 2003.

13. Cid, N.; Bonada, N.; Carlson, S.; Grantham, T.; Gasith, A.; Resh, V. High Variability is a Defining Component of Mediterranean-Climate Rivers and Their Biota. Water 2017, 9, 52. [CrossRef]

14. Chapple, D.; Faber, P.; Suding, K.; Merenlander, A. Climate Variability Structures Plant Comnmunity Dynamics in Mediterranean Restored and Reference Tidal Wetlands. Water 2017, 9, 209. [CrossRef]

15. Woelfle-Erskine, C. Collaborative Approaches to Flow Restoration in Intermittent Salmon-Bearing Streams: Salmon Creek, CA, USA. Water 2017, 9, 217. [CrossRef]

16. Deitch, M.J. Scientific and Institutional Complexities of Managing Surface Water for Beneficial Human and Ecosystem Uses under a Seasonally Variable Flow Regime in Mediterranean-Climate Northern California. Ph.D. Thesis, UC Berkeley, Berkeley, CA, USA, 2006.

17. Mullan, A. An Examination of California Salmon Management: Klamath River Populations, Ocean Fleet Dynamics and Advocacy Coalition. Ph.D. Thesis, University of California Santa Cruz, Santa Cruz, CA, USA, 2003.

18. Kahrl, W. (Ed.) California Water Atlas; prepared by the Governor's Office of Planning and Research in cooperation with the California Department of Water Resources; State of California, General Services, Publications Section: North Highland, CA, USA, 1979.

19. Kahrl, W. Water and Power; University of California Press: Berkeley, CA, USA, 1982.

20. Kelley, R. Battling the Inland Sea; University of California Press: Berkeley, CA, USA, 1998.

21. Eisenstein, W.; Kondolf, M.; Cain, J. ReEnvisioning the Delta: Alternative Futures for the Heart of California; Institute of Urban and Regional Development, University of California: Berkeley, CA, USA, 2007.

22. Conrad, E. Regional Governance of Flood Management in the Central Valley: An Analysis of the Integrated Regional Water Management and Regional Flood Management Programs; California Department of Water Resources: Sacramento, CA, USA, 2014.

23. Langridge, R.; Christian-Smith, J.; Lohse, K.A. Access and resilience: Analyzing the construction of social resilience to the threat of water scarcity. Ecol. Soc. 2006, 11, 18. [CrossRef]

24. Lilienthal, D. TVA: Democracy on the March; Harper: New York, NY, USA, 1944.

25. Eckstein, O. Water Resource Development: The Economics of Project Evaluation; Harvard: Cambridge, MA, USA, 1944.

26. Krutilla, J.; Eckstein, O. Multiple Purpose River Development; Resources for the Future Press: Washington, DC, USA, 1958.

27. Romm, J. Jurisdictional Relations in Ecosystem Management: Some Observations from California. In Ecosystem Management: Status and Potential, Library Congress; Congressional Research Service, Ed.; US Printing Office: Washington, DC, USA, 1994; pp. 97-106.

28. Romm, J. What Is Watershed Stability? Lessons from science, policy and practice. In The Pursuit of Watershed Stability; Water Resources Center Report No. 92; Somarstrom, S., Ed.; University of California: Berkeley, CA, USA, 1997.

29. Merenlender, A.; Deitch, M.; Feirer, S. Decision Support Tool Seeks to Aid Stream-Flow Recovery and Enhance Water Security. Calilf. Agric. 2008, 62, 148-155. [CrossRef]

30. Deitch, M.J.; Kondolf, G.M.; Merenlender, A.M. Hydrologic impacts of small-scale in-stream diversions for frost and heat protection in the California wine country. River Res. Appl. 2008, 25, 118-134. [CrossRef]

31. Innes, J.; Booher, D. Planning with Complexity; Routledge: New York, NY, USA, 2010.

32. Connick, S. The Use of Collaborative Processes in the Making of California Water Policy. Ph.D. Thesis, University of California, Berkeley, CA, USA, 2003.

33. Conrad, E. Bridging the Hierarchical and Collaborative Divide: LEARNING in California's Integrated Regional Water Management Process. Ph.D. Thesis, University of California, Berkeley, CA, USA, 2015.

34. Andrew, J.; Sauquet, E. Climate Change Impacts and Water Management Adaptation in Two Mediterranean-Climate Watersheds: Learning from the Durance and Sacramento Rivers. Water 2017, 9, 126. [CrossRef] 
35. Chang, P. The Feather River Coordinated Resource Management Group (CRMP): Regionalism and Federalism in Watershed Management. Master's Thesis, University of California, Berkeley, CA, USA, 2002.

36. DiVittorio, S. Collaborative Governance in the Feather River Basin. Ph.D. Thesis, University of California, Berkeley, CA, USA, 2014.

37. Doremus, H.; Tarlock, A.D. Water War in the Klamath Basin; Island Press: Washington, DC, USA, 2008.

38. Scott, J. Seeing Like a State; Yale University Press: New Haven, CT, USA, 1998.

39. Nadel, S.F. The Theory of Social Structure; Free Press: Glencoe, IL, USA, 1958.

40. Langridge, R. Shifting Legal regimes and the allocation of water between two Northern California Watersheds. Nat. Resour. Law J. 2002, 42, 238-330.

41. Dworsky, L.; Allee, D.; North, R. Water resources planning and management in the United States federal system: Long-term assessment and intergovernmental issues. Nat. Res. J. 1991, 34, 475-547.

42. Serra-Llobet, A.; Conrad, E.; Schaefer, K. Governing for integrated water and flood risk management: Comparing approaches in Spain and California. Water 2016, 8, 445. [CrossRef]

43. Thomas, C. Bureaucratic Landscapes: Interagency Cooperation and the Preservation of Biodiversity; MIT Press: Cambridge, MA, USA, 2003.

44. Ostrom, E. Governing the Commons: The Evolution of Institutions for Collective Action; Cambridge University Press: Cambridge, MA, USA, 1990.

45. Reid, W.; Berkes, F.; Wilbanks, T.; Capistrano, D. (Eds.) Bridging Scales and Knowledge Systems: Concepts and Applications in Ecosystem Assessment; Island Press: Washington, DC, USA, 2005.

46. Garmetani, A.; Benson, M. A Framework for Resilience-Based Governance of Socio-Ecological Systems. Ecol. Soc. 2013, 18, 9.

47. Moore, M.; Westley, F. Surmountable Chasms: Networks and Social Innovation for Resilient Systems. Ecol. Soc. 2011, 16, 5. [CrossRef]

48. Selznick, P. TVA and the Grass Roots: A Study in the Sociology of Formal Organization; University of California Press: Berkeley, CA, USA, 1949.

49. Olson, M. The Logic of Collective Action: Public Goods and the Theory of Groups; Harvard University Press: Cambridge, MA, USA, 1965.

50. Connick, S.; Innes, J.E. Outcomes of collaborative water policy making: Applying complexity thinking to evaluation. J. Environ. Plan. Manag. 2003, 46, 177-197. [CrossRef]

51. Heikkila, T.; Gerlak, A. The formation of large-scale collaborative resource management institutions: Clarifying the roles of stakeholders, science, and institutions. Policy Stud. J. 2005, 33, 583-612. [CrossRef]

52. Balazs, C. Just Water? Social Disparities and Drinking Water Quality in California's San Joaquin Valley. Ph.D. Thesis, UC Berkeley, Berkeley, CA, USA, 2011.

53. Romm, J.; Fairfax, S. The Backwaters of Federalism: Receding Reserved Water Rights and the Management of National Forests. Policy Stud. Rev. 1985, 5, 413-430. [CrossRef]

54. Romm, J.; Calaham, R.Z.; Kattelmann, R.C. Toward Managing Sierra Nevada Forests for Water Supply; Wildland Resources Center Report 17; University of California: Berkeley, CA, USA, 1988.

55. Ewing, A. The Agricultural Value of National Forest Water in California. Master's Thesis, Wildland Resource Science, University of California, Berkeley, CA, USA, 1985.

56. Porter, B.; Routledge, B.; Simmons, E.; Lev-Tov, J. Extensification in a Mediterranean Semi-Arid Marginal Zone: An Archeological Case Study from Early Iron Age Jordan's Eastern Karak Plateau. J. Arid Environ. 2014, 104, 132-148. [CrossRef]

57. Måren, I.E.; Bhattarai, K.R.; Chaudhary, R.P. Forest ecosystem services and biodiversity in contrasting Himalayan forest management systems. Environ. Conserv. 2013, 41, 73-83. [CrossRef]

58. Måren, I.E.; Karki, S.; Prajapati, C.; Shrestha, B.B.; Yadav, R.K. In semiarid environments, does slope aspect matter to woody species composition, carbon stocks and soil properties? An example from a trans-Himalayan valley. J. Arid Environ. 2015, 121, 12-123.

59. Braunsworth, W.; Welch, T.; Hathaway, R.L. (Eds.) Water Allocation in the Klamath Reclamation Project, 2001; Oregon State University Extension Service Special Report 1037; Oregon State University Extension Service: Corvallis, OR, USA, 2002.

60. Most, S. River of Renewal; Oregon Historical Society Press: Portland, OR, USA, 2006.

61. United States v. Winans. 198 U.S. 371, 25 Supreme Court 662. 1905. Available online: https:/ / supreme.justia. com/cases/federal/us/198/371/case.html (accessed on 5 February 2018). 
62. Washington v. Fishing Vessel Association. 443 U.S. 658, 99 Supreme Court 3055. 1979. Available online: https:/ / supreme.justia.com/cases/federal/us/443/658/ (accessed on 5 February 2018).

63. United States v. Adair. 723 F. 2d. 1394 U.S. Court of Appeals 9th Circuit. 1983. Available online: https: / / openjurist.org/723/f2d/1394/united-states-v-adair (accessed on 5 February 2018).

64. Verghese, B.G. Waters of Hope, 4th ed.; India Research Press: New Delhi, India, 2007.

65. Khan, H.; Romm, J. Water Resource Issues in Bangladesh; Ford Foundation: Dhaka, Bangladesh, 1979.

66. Crow, B. Sharing the Ganges; Sage Publications: New Delhi, India, 1995.

67. Rose, L.; Romm, J.; Crow, B. Regional Arrangements for Environmental Security and Sustainable Development in the Ganges-Brahmaputra Basin; Unpublished Paper Prepared for the United Nations Development Programme; United Nations Development Programme: New York, NY, USA, 1997.

68. Royal Haskoning. Controlling or Living with Floods in Bangladesh; ARD Working Paper 10; International Bank for Reconstruction and Development: Washington, DC, USA, 2003.

69. Clinton, R.; Goldberg, C.; Tsosie, R. American Indian Law: Native Nations and the Federal System, 4th ed.; LexisNexis: New York, NY, USA, 2003.

70. Getches, D.; Wilkinson, C.; Williams, R. Federal Indian Law, 5th ed.; Thomson West: St. Paul, MN, USA, 1998.

71. Barlowe, R. Land Resource Economics, 4th ed.; Prentice Hall: Upper Saddle River, NJ, USA, 1986.

72. National Research Council. Scientific Evaluation of Biological Opinions on Endangered and Threatened Fishes in the Klamath River Basin; National Academy Press: Washington, DC, USA, 2002.

73. Central Valley Project Improvement Act. Public Law 102-575, as Amended. 1986. Available online: https: / /www.usbr.gov/mp/cvpia/title_34/public_law_complete.html (accessed on 5 February 2018).

74. Hoopa Valley Indian Tribe v. Ryan. 415F.3rd.986. 2005. Available online: http://caselaw.findlaw.com/us9th-circuit/1085609.html (accessed on 5 February 2018).

75. Schmidt, S. Evolving Relations between Farmers and Fish in the Klamath River Basin: Methods for Improving Agricultural Use and Efficiency in the Shasta and Scott Valleys. Bachelor's Thesis, University of California, Berkeley, CA, USA, 2009.

76. Doyle, M. A fight between farmers and tribes over Northern California water. Sacramento Bee. 2 September 2015. Available online: http:/ / www.sacbee.com/news/state/california/water-and-drought/ article33417963.html (accessed on 6 February 2018).

77. Wengert, N.; Dyer, A.; Deutsch, S. The "Purposes" of the National Forests; Colorado State University: Ft. Collins, CO, USA, 1979

78. Hill, B. Evaluating Effects of Meadow Restoration on Summer Streamflow; US Forest Service: Quincy, CA, USA, 2011.

79. Science and Technology editor. Fears That California's Huge Oroville Dam Will Fail Have Subsided-For Now. Economist. 24 February 2017. Available online: https://www.economist. com/news/science-and-technology/21717324-fears-californias-huge-oroville-dam-might-fail-havesubsidedfor-time-being-drought (accessed on 5 February 2018).

80. Gray, G.; Enzer, M.; Kusel, J. Understanding Community-Based Forest Ecosystem Management; Haworth Press: New York, NY, USA, 2001.

81. Baker, M.; Kusel, J. Community Forestry in the United States; Island Press: Washington, DC, USA, 2003.

82. Loheide, S.P., II; Gorelick, S.M. Riparian hydroecology: A coupled model of the observed interactions between groundwater flow and meadow vegetation patterning. Water Resour. Res. 2007, 43, W07414. [CrossRef]

83. Hammersmark, C.; Rains, M.; Mount, J. Quantifying the hydrological effects of stream restoration in a montane meadow, Northern California. River Res. Appl. 2008, 24, 735-753. [CrossRef]

84. Anderson, H.; Hoover, M.; Reinhart, K. Forests and Water: Effects of Forest Management on Floods, Sedimentation and Water Supply; General Technical Report PSW-018; U.S. Department of Agriculture, Forest Service, Pacific Southwest Forest and Range Experiment Station: Berkeley, CA, USA, 1976.

85. Krutilla, J.; Bowes, M.; Sherman, P. Watershed Management for Joint Production of Water and Timber: A Provisional Assessment. Water Resour. Bull. 1983, 19, 403-414. [CrossRef]

86. Kattelmann, R. Effects of Forest Cover on a Snowpack in the Sierra Nevada. In Watershed Planning and Analysis in Action; Riggins, R., Jones, E., Singh, R., Rechard, P., Eds.; American Society of Civil Engineers: New York, NY, USA, 1990; pp. 276-284.

87. Millar, C.I. Sierra Nevada Ecosystem Project. Sierra Nevada Ecosystem Project, Final Report to Congress, Vol. I.; Centers for Water and Wildland Resources Report No. 36; University of California: Davis, CA, USA, 1996. 
88. Romm, J. Tension between the Science and the Management of Watersheds: The Need for a Public Science. In Watersheds '94, Wildland Resources Center Report No. 86; Erman, D., Ed.; University of California: Berkeley, CA, USA, 1996.

89. Norgaard, R.; Kallis, G.; Kiparsky, M. Collectively engaging complex socio-ecological systems: Reenvisioning science, governance, and the California Delta. Environ. Sci. Policy 2009, 12, 644-652. [CrossRef]

90. Innes, J.; Connick, S.; Booher, D.E. Informality as a planning strategy: Collaborative water management in the CALFED Bay-Delta Program. J. Am. Plan. Assoc. 2007, 73, 195-210. [CrossRef]

91. Innes, J.; Connick, S.; Kaplan, L.; Booher, D. Collaborative Governance in the CALFED Program; Working Paper 2006-01; Institute of Urban and Regional Development, University of California: Berkeley, CA, USA; Center for Collaborative Policy, California State University: Sacramento, CA, USA, 2006.

2018 by the authors. Licensee MDPI, Basel, Switzerland. This article is an open access article distributed under the terms and conditions of the Creative Commons Attribution (CC BY) license (http:/ / creativecommons.org/licenses/by/4.0/). 